\title{
Effects of reservoirs water level variations on fish recruitment
}

\author{
Fabíula T. de Lima' ${ }^{1}$, David A. Reynalte-Tataje ${ }^{2}$ and Evoy Zaniboni-Filho ${ }^{3}$
}

The construction of hydroelectric power plants has many social and environmental impacts. Among them, the impacts on fish communities, which habitats are drastically modified by dams, with consequences across the ecosystem. This study aimed to assess the influence of water level (WL) variations in the reservoirs of the Itá and Machadinho hydroelectric plants on the recruitment of fish species from the upper Uruguay River in southern Brazil. The data analyzed resulted from the WL variation produced exclusively by the hydroelectric plants generation and were collected between the years 2001 and 2012. The results showed significant correlations between the abundance of juvenile fish and the hydrological parameters only for some reproductive guilds. The species that spawn in nests showed, in general, a clear preference for the stability in the WL of the reservoirs, while the species that spawn in macrophytes or that release demersal eggs showed no significant correlation between the abundance of juvenile fish and hydrological parameters. A divergence of results between the two reservoirs was observed between the species that release semi-dense eggs; a positive correlation with a more stable WL was only observed in the Machadinho reservoir. This result can be driven by a wider range of WL variation in Machadinho reservoir.

Keywords: Hydrological Parameters, Itá, Juveniles, Machadinho, Reproduction, Uruguay River.

A construção de usinas hidrelétricas implica em diversos impactos sociais e ambientais. Dentre esses, o impacto causado sobre a comunidade de peixes, cujos habitats são drasticamente modificados pelas barragens, causam consequências em todo o ecossistema. Este trabalho teve como objetivo avaliar a influência da variação dos níveis de água dos reservatórios das usinas hidrelétricas de Itá e Machadinho sobre o recrutamento das espécies de peixes do alto rio Uruguai, sul do Brasil. Os dados analisados resultaram da variação de nível de água decorrente exclusivamente da operação da usina e foram coletados entre os anos de 2001 e 2012. Os resultados mostraram correlações significativas entre a abundância dos juvenis de peixes e os parâmetros hidrológicos apenas para determinadas guildas reprodutivas. As espécies que desovam em ninhos mostraram, em geral, uma clara preferência pela estabilidade do nível de água dos reservatórios, enquanto que as espécies que desovam em macrófitas ou que liberam ovos demersais não mostraram correlação significativa entre a abundância de juvenis com os parâmetros hidrológicos. Uma divergência de resultados entre os dois reservatórios foi observada entre as espécies que liberam ovos semi-densos, onde apenas no reservatório de Machadinho houve correlação positiva com a maior estabilidade do nível de água. Esse resultado pode ser motivado pela maior amplitude de variação do nível de água no reservatório de Machadinho quando comparado com o de Itá.

Palavras-chave: Itá, Juvenis, Machadinho, Parâmetros Hidrológicos, Reprodução, Rio Uruguai.

\section{Introduction}

The damming of rivers is an intense and dramatic process that results in the creation of a new ecosystem with other structures, biota and functioning; therefore, the occurrence of environmental impacts is inherent in any impoundment, a process fundamentally connected to the river flow control (Agostinho et al., 2004a). Despite describing a single hydrological attribute, water flow is the key driving force in freshwater ecosystems and it is responsible for their geological/hydrological structure, dynamics of production (material and energy), nutrient cycling and distribution and evolution of biota (Agostinho et al., 2004b).
Biogeochemical cycles are strongly influenced by periodic increases in water levels, because in addition to the direct exchange of nutrients resulting from this dynamics, floods promote nutrient pulses from the decomposition of flooded vegetation. The primary productivity and the biophysical responses of the aquatic vegetation, and of several taxa of invertebrates, are also dependent on the flood pulse (Agostinho et al., 2004a). Water levels have a direct effect on the abundance of periphyton, aquatic macrophytes and benthos, and even an indirect effect on phytoplankton and zooplankton. Fluctuations may be daily, seasonally or annually, largely depending on the purpose of the reservoir, and present many problems related to the management of fish habitat (Miranda, 2001).

'Programa de Pós-Graduação em Aquicultura (PPG-AQI), Universidade Federal de Santa Catarina, Rodovia Admar Gonzaga, n 1346, 88034-000 Florianópolis, SC, Brazil. biapaixonada@gmail.com

${ }^{2}$ Centro de Ciências Biológicas, Universidade Federal da Fronteira Sul, Campus Cerro Largo, Rua Major Antônio Cardoso, n 590, Bloco A, 97900-000 Cerro Largo, RS, Brazil. reynalted@hotmail.com

${ }^{3}$ Laboratório de Biologia e Cultivo de Peixes de Água Doce (LAPAD), Universidade Federal de Santa Catarina, Rodovia SC 406, n 3532 , 88066-000 Florianópolis, SC, Brazil. evoy@lapad.ufsc.br (corresponding author) 
The shorelines of reservoirs tend to be highly unstable when the water levels float (Agostinho et al., 2007). Increases in water levels that temporarily flood vegetation increase food and shelter supply, while prolonged droughts concentrate fish populations and may increase foraging efficiency by predators (Miranda, 2001). The reproduction of species that spawn on the shoreline is favored if the water levels increase during spawning season, but their survival may be affected if water levels rapidly change during the reproductive period, especially for those species that are nest builders or that spawn on the substrate (Agostinho et al., 2007).

Many studies have been conducted to assess the influence of WL variations on the community of fish or other aquatic organisms (Pompeu, Godinho, 2006; Paulovits et al., 2007; Baumgärtner et al., 2008; Zohary, Ostrovsky, 2011; Dutterer et al., 2013). These studies demonstrated that both the fluctuations of water levels in natural environments (caused by annual cycle and climate change), as well as in reservoirs and other artificial water bodies, promoted impacts on the fish communities and other components of the aquatic biota, as well as in water quality parameters.

The region of the upper Uruguay River is formed by well-embedded and rather steep valleys, with absence of floodplain (Reynalte-Tataje et al., 2012b). This environment favors a flash floodongs with rapid rise in hours during periods of heavy rainfall (Corrêa et al., 2011). Due to such regional features, it is expected that variations in water levels in the reservoirs will negatively influence the recruitment of juveniles of the existing species of fish.

Most existing studies in Brazil were conducted in other river basins, especially in the Paraná River Basin (Agostinho et al., 2004a; Agostinho et al., 2004b; Fernandes et al., 2009; Gubiani et al., 2010; Petry et al., 2013). There is a lack of studies assessing the influence of water levels variations on the neotropical ichthyofauna located in a subtropical region, such as the upper Uruguay River. Considering the importance of this knowledge for the conservation and management of fisheries resources, the aim of this study was to assess the influence of changes in water levels in two reservoirs with different intensity of WL variation on the recruitment of juvenile fish. The hypothesis is that the recruitment of juvenile fish species from different reproductive guilds is affected differently by the variation of WL from reservoir.

\section{Materials and Methods}

Study area. The region of the upper Uruguay River (Zaniboni-Filho, Schulz, 2003) has great potential for hydroelectric facilities, and the first two power plants were built in this region in Itá in 1999 and in Machadinho in 2002. The Itá HPP (hydroelectric power plant) is located between the municipalities of Itá (SC) and Aratiba (RS) (27 16'39.1" $\mathrm{S}-52$ 22' 56.9" $\mathrm{W}$ and the reservoir maximum WL is $375 \mathrm{~m}$ above sea level), and is $1,529 \mathrm{~km}$ upstream far from the mouth of the Uruguay River (Meurer, 2010). The reservoir formed has a total area of $141 \mathrm{~km}^{2}$, being a run-ofthe-river and designed for WL variations of approximately $6 \mathrm{~m}$ (Tractebel Energia, 2013). The reservoir has an average depth of $36 \mathrm{~m}$ and maximum of $125 \mathrm{~m}$. The mean water residence time is 55 days.

The Machadinho HPP dam is located in the Pelotas River on the border between the municipalities of the Brazilian cities of Piratuba (SC) and Maximiliano de Almeida (RS) (27 31'37" S - 51 47'06" $\mathrm{W}$ and the reservoir maximum WL is $485 \mathrm{~m}$ above sea level). The reservoir is also run-of-theriver and has a total area of $79 \mathrm{~km}^{2}$, an average depth of 43 $\mathrm{m}$ and a maximum depth of $100 \mathrm{~m}$ and was designed for a maximum rise in the reservoir's WL of $15 \mathrm{~m}$ (Consórcio Machadinho, 2013). The mean water residence time in the reservoir is 54 days.

Sampling. The data used in this study were collected between the years 2000 and 2012 for the Itá reservoir, and between 2001 and 2012 for the Machadinho reservoir. Samples were collected every three months to represent different seasons. The study area comprised eight sampling sites, three located in the Machadinho reservoir and five in the Itá reservoir (Fig. 1):

Machadinho reservoir: MR1: Transition area between lotic and lentic environments. MR2: Lentic environment located in the body of the reservoir. MR3: Lentic environment located in the body of the reservoir just upstream the dam.

Itá reservoir: IR1: Transition area between lotic and lentic environments. IR2: Transition area between lotic and lentic environments, located almost $10 \mathrm{~km}$ far from IR1. IR3: Upper section of the reservoir in a lotic environment. IR4: Middle section of the reservoir. IR5: Lower section of the reservoir located just upstream the dam.

Samplings were performed using fishing gears as gill nets and trammel nets with different mesh sizes from 1.5 $\mathrm{cm}$, seine and cast nets. The fishing gears were placed in the water on the evening of one day and removed at dawn the next day, remaining approximately 12 hours in the water; except for the seine and cast nets, which were thrown in the water three times during mornings.

Biological and hydrological data. For the assessment of the recruitment, only juvenile specimens were considered, those that were below the size of first gonadal maturation of each species $\left(\mathrm{L}_{100}\right)$, i.e., the length at which all individuals in the population are able to reproduce.

For purposes of analysis, only the fish species that showed abundance higher than 10 juveniles caught during the study period, and for which there is reference information of $\mathrm{L}_{100}$. For $\mathrm{L}_{100}$ information was used: Agostinho, Hahn (1991), Vazzoler (1996), Santos, Fontoura (2000), Veregue, Orsi (2003), Alves (2009), and Froese, Pauly (2017).

The species were grouped according into four reproductive strategy and categories, according to Nakatani et al. (2001) and Reynalte-Tataje, Zaniboni-Filho (2008): spawning in nests, spawning in macrophytes, releases of 


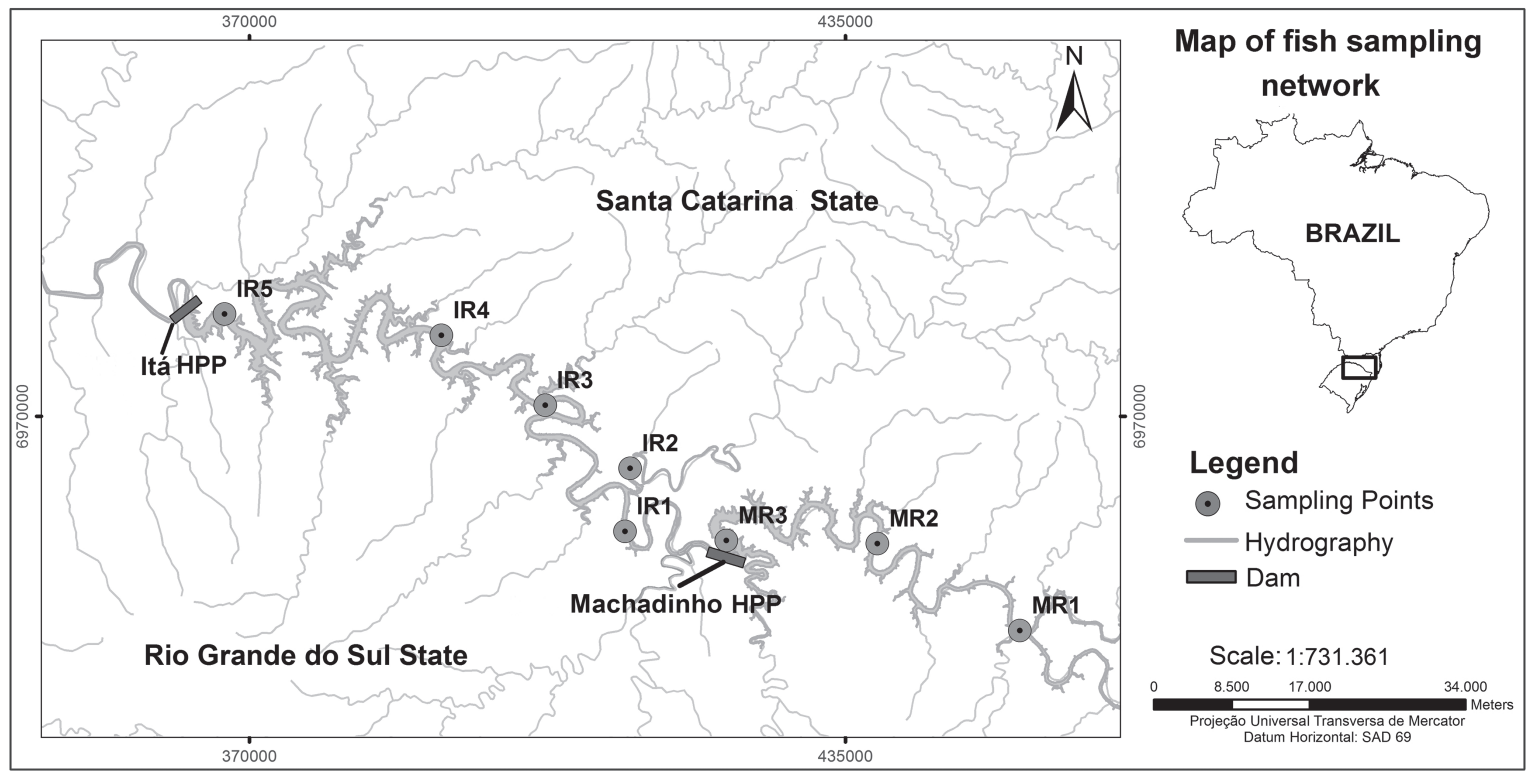

Fig. 1. Study area and location of sampling points at the Machadinho and Itá reservoirs.

semi-dense eggs and releases of demersal eggs. This division was performed to assess the effect of different reservoir water levels on each reproductive guild.

The hydrological data of the reservoirs were provided by the operation sector of each of the power plants. The daily raw data of the hydrological levels was used to estimate the daily water volume. Using the standard deviation and average of these daily data of WL and water volume, the following variables were calculated: Variation of the Reservoir Water Level (VRWL), Variation of the Storage Volume (VSV), Average Value of the Reservoir Water Level (AVRWL), and Average Value of the Storage Volume (AVSV).

These parameters were calculated for each reproductive period (RP) studied, between October and February. Therefore, in the period assessed, the hydrological values of 12 RP were calculated: RP1 = October 2000 to February $2001(2000-2001), \mathrm{RP} 2=2001-2002, \mathrm{RP} 3=2002-2003$, $\mathrm{RP4}=2003-2004, \mathrm{RP} 5=2004-2005, \mathrm{RP} 6=2005-2006$, $\mathrm{RP} 7=2006-2007, \mathrm{RP} 8=2007-2008, \mathrm{RP} 9=2008-2009$, $\mathrm{RP} 10=2009-2010, \mathrm{RP} 11=2010-2011$, and RP12 $=2011-$ 2012.

Voucher specimens are deposited in the Museu de Zoologia, Universidade Estadual de Londrina (MZUEL) under the voucher numbers presented in Table 3 .

Data analysis. The hydrological parameters were obtained using the daily raw data of the hydrological levels of each reservoir and were calculated for each reproductive period. To obtain the hydrological parameters related to the variations in the water levels and the storage volume of the reservoirs (VRWL e VSV, respectively), standard deviation calculations were performed, while the hydrological parameters related to the WL average and the storage volume (AVRWL and AVSV, respectively) were obtained by calculating the average of the data.
To summarize the structure of the juvenile fish community in relation to the years, a Detrended Correspondence Analysis (DCA) was applied to the species abundance data using the PCord 5.0 software. This analysis was conducted from the year 2004 for the Itá reservoir and from 2005 for the Machadinho reservoir to exclude the first four years after the formation of each reservoir, when a greater variation in the structure of fish community assembly is expected (ZaniboniFilho et al., 2008). This initial disturbance was observed in Itá reservoir (Meurer, 2010) and Machadinho reservoir (Reynalte-Tataje et al., 2012d). In this study, a gradual reduction in the total number of juveniles captured annually in the first four years was observed for both reservoirs.

The Pearson correlation was used to analyze the existence of a relationship between the hydrologic parameters of each reproductive period and the abundance of juvenile fish. Two correlations were performed, one covering the entire period of study and another starting from the fourth year after the filling of each of the reservoirs studied, which also sought to remove the effect of the first years of reservoir formation on the structure of fish community. Correlations above 0.40 were considered significant.

\section{Results}

Hydrological parameters. The WL of the Machadinho reservoir showed an annual variation from $0.79 \mathrm{~m}$ to $3.88 \mathrm{~m}$ and the average values of the water levels ranged from $473 \mathrm{~m}$ to $479 \mathrm{~m}$ (Tab. 1). The WL in the Itá reservoir ranged from 0.42 $\mathrm{m}$ to $1.81 \mathrm{~m}$ and the average values of the annual water levels ranged from $366 \mathrm{~m}$ to $369 \mathrm{~m}$ (Tab. 2). The annual variation in the storage volume of water was similar between both reservoirs and ranged from near $6 \%$ to $28 \%$. Otherwise, the range of the average value of the WL was double in Machadinho reservoir $(6 \mathrm{~m})$ when compared with Itá reservoir $(3 \mathrm{~m})$. 
Tab. 1. Hydrological parameters for each reproductive period (RP2-RP12) in the Machadinho reservoir. ${ }^{1}$ Reproductive period $=$ RP2: spring/2001 to summer/2002, RP3: spring/2002 to summer/2003;...; RP12: spring/2011 to summer/2012. ${ }^{2} \mathrm{AWL}=$ Average value of the water level of the reservoir during the reproductive period. ${ }^{3} \mathrm{VWL}=$ Variation (standard deviation) of the water level of the reservoir during the reproductive period. ${ }^{4} \mathrm{ASV}$ $=$ Average value of the storage volume of the reservoir during the reproductive period. ${ }^{5} \mathrm{VSV}=$ Variation (standard deviation) of the storage volume of the reservoir during the reproductive period.

\begin{tabular}{lcccc}
\hline & \multicolumn{4}{c}{ Hydrological parameters } \\
\cline { 2 - 5 } Reproductive period & AWL $(\mathrm{m})$ & VWL $^{3}(\mathrm{~m})$ & $\begin{array}{c}\text { Relative } \\
\mathrm{ASV}^{4}(\%)\end{array}$ & $\begin{array}{c}\text { Relative } \\
\text { VSV }^{5}(\%)\end{array}$ \\
\hline RP2 & 477 & 1.99 & 76.9 & 14.2 \\
RP3 & 478 & 3.07 & 83.6 & 21.6 \\
RP4 & 473 & 3.71 & 50.4 & 25.2 \\
RP5 & 475 & 3.66 & 67.4 & 25.5 \\
RP6 & 476 & 2.56 & 74.0 & 18.2 \\
RP7 & 473 & 2.45 & 52.6 & 16.6 \\
RP8 & 475 & 3.88 & 65.0 & 26.9 \\
RP9 & 475 & 3.79 & 64.9 & 26.4 \\
RP10 & 479 & 0.79 & 95.7 & 5.75 \\
RP11 & 473 & 3.86 & 48.9 & 26.2 \\
RP12 & 473 & 3.11 & 53.2 & 21.2 \\
\hline
\end{tabular}

Tab. 2. Hydrological parameters for each reproductive period (RP1-RP12) in the Itá reservoir. ${ }^{1}$ Reproductive period $=$ RP1: spring $/ 2000$ to summer/2001; RP2: spring/2001 to summer/2002;...; RP12: spring/2011 to summer/2012. ${ }^{2} \mathrm{AWL}=$ Average value of the water level of the reservoir during the reproductive period. ${ }^{3} \mathrm{VWL}=$ Variation (standard deviation) of the water level of the reservoir during the reproductive period. ${ }^{4} \mathrm{ASV}=$ Average value of the storage volume of the reservoir during the reproductive period. ${ }^{5} \mathrm{VSV}=$ Variation (standard deviation) of the storage volume of the reservoir during the reproductive period.

\begin{tabular}{lcccc}
\hline & \multicolumn{4}{c}{ Hydrological parameters } \\
\cline { 2 - 5 } Reproductive period & nWL $(\mathrm{m})$ & $\mathrm{VWL}^{3}(\mathrm{~m})$ & $\begin{array}{c}\text { Relative } \\
\mathrm{ASV}^{4}(\%)\end{array}$ & $\begin{array}{c}\text { Relative } \\
\mathrm{VSV}^{5}(\%)\end{array}$ \\
\cline { 2 - 5 } RP1 & 369 & 1.01 & 88.2 & 17.7 \\
RP2 & 366 & 1.73 & 43.5 & 29.1 \\
RP3 & 369 & 0.95 & 86.5 & 16.5 \\
RP4 & 367 & 1.32 & 56.9 & 22.3 \\
RP5 & 368 & 1.37 & 70.3 & 23.7 \\
RP6 & 369 & 0.70 & 82.0 & 11.9 \\
RP7 & 367 & 1.15 & 51.1 & 19.1 \\
RP8 & 367 & 1.81 & 56.0 & 30.5 \\
RP9 & 368 & 1.06 & 69.6 & 18.3 \\
RP10 & 369 & 0.42 & 93.4 & 7.5 \\
RP11 & 368 & 1.60 & 60.0 & 26.9 \\
RP12 & 368 & 0.89 & 64.3 & 15.2 \\
\hline
\end{tabular}

Abundance of juveniles fish. The Machadinho reservoir showed a total of 1,260 juveniles spread among 12 species (Tabs. 3-4). The species that spawn in nests and/ or macrophytes (total of 3 species) contributed with 405 juveniles (32.1\% of the total catch), while species that release semi-dense eggs or demersal eggs (total of 9 species) with totalized 855 juveniles $(67.9 \%)$. The species that showed the largest abundance of juveniles was Geophagus brasiliensis, with a total of 281 individuals collected, followed by Piabarchus stramineus (=Bryconamericus stramineus) (215) and Astyanax lacustris (200).

The Itá reservoir showed a total of 4,642 juveniles spread among 18 species (Tabs. 3-4). The species that spawn in nests and/or macrophytes (total of 5 species) contributed with 609 juveniles (13.1\% of the total catch), while the species that release semi-dense eggs or demersal eggs (total of 13 species) contributed with 4,033 juveniles $(86.9 \%)$. The species that showed the largest abundance of juveniles was Apareiodon affinis, with a total of 1,693 individuals collected, followed by Piabarchus stramineus (656), Astyanax aff. fasciatus (525) and Iheringichthys labrosus (520).

A continuous decline in total juveniles collected in the first four years after the formation of both reservoirs can be observed in Fig. 2 (from 2001 to 2004 for Itá and from 2002 to 2005 for Machadinho). In the following years, small fluctuations in the abundance of juveniles occurred and there was a discrete synchronization of this oscillation in the abundance between both reservoirs.

Detrended Correspondence Analysis (DCA). The DCA for the Machadinho reservoir explained 52.3\% of the data variability on the abundance of juveniles considering all sampling years throughout the study period, which shows a variation in the temporal distribution of the species (Fig. 3).

DCA 1 represented $42.7 \%$ of the total variation of the data and showed a segregation in the years 2005, 2006, 2009 and 2010 , which were characterized by a greater abundance of Eigenmania virescens $(\mathrm{r}=0.62 ; \mathrm{p}<0.05)$, A. affinis $(\mathrm{r}=0.47$; $\mathrm{p}<0.05)$, A. fasciatus $(\mathrm{r}=0.72 ; \mathrm{p}<0.05)$, B. stramineus $(\mathrm{r}=$ $0.70 ; \mathrm{P}<0.05)$ and Oligosarcus jenynsii $(\mathrm{r}=0.48 ; \mathrm{P}<0.05)$. As for the other years, they were characterized by a greater abundance of $A$. lacustris $(\mathrm{r}=-0.91 ; \mathrm{p}<0.05)$. The DCA 2 was disregarded due to the low percentage of explanation $(9.6 \%)$.

The DCA for the Itá reservoir explained $50 \%$ of the data variability of abundance of juveniles in the different sampling years, considering the whole period analyzed, revealing a variation in the temporal species distribution (Fig. 4). The DCA 1 showed $34.6 \%$ of the total variation of the data and showed a clear segregation in the year 2012 in relation to the other years assessed. The year 2012 was characterized by the presence of A. fasciatus $(\mathrm{r}=0.90 ; \mathrm{p}<0.05)$ and A. lacustris $(\mathrm{r}=0.86 ; \mathrm{p}<0.05)$. 
Tab. 3. List of fish species collected (X) during the sampling period in the Machadinho and Itá reservoirs. Voucher specimens number deposited in the Museu de Zoologia, Universidade Estadual de Londrina (MZUEL) and the reproductive strategy category.

\begin{tabular}{|c|c|c|c|c|}
\hline \multirow{2}{*}{ Species } & \multirow{2}{*}{ Voucher Specimens } & \multirow{2}{*}{ Reproductive strategy } & \multicolumn{2}{|c|}{ Reservoir } \\
\hline & & & Itá & Machadinho \\
\hline Acestrorhynchus pantaneiro Menezes, 1992 & MZUEL 5777/9495 & Semi-dense eggs & $\mathrm{X}$ & $\mathrm{X}$ \\
\hline Apareiodon affinis (Steindachner,1879) & MZUEL 10550/10552 & Semi-dense eggs & $\mathrm{X}$ & $\mathrm{X}$ \\
\hline Astyanax aff. fasciatus (Cuvier, 1819) & MZUEL 10231/10234 & Demersal eggs & $\mathrm{X}$ & $\mathrm{X}$ \\
\hline Astyanax aff. scabripinnis (Jenyns, 1842) & MZUEL 10286 & Semi-dense eggs & $\mathrm{X}$ & \\
\hline Astyanax jacuhiensis (Cope, 1894) & MZUEL 10285/10235 & Demersal eggs & $\mathrm{X}$ & $\mathrm{X}$ \\
\hline Cyprinus carpio Linnaeus, 1758 & MZUEL 11730 & Macrophytes & & $\mathrm{X}$ \\
\hline Eigenmannia virescens (Valenciennes, 1836) & MZUEL 10557 & Macrophytes & & $\mathrm{X}$ \\
\hline Geophagus brasiliensis (Quoy \& Gaimard, 1824) & MZUEL 10230 & Nest & $\mathrm{X}$ & $\mathrm{X}$ \\
\hline Hoplias lacerdae Miranda Ribeiro, 1908 & MZUEL 10438 & Nest & $\mathrm{X}$ & \\
\hline Hoplias malabaricus (Bloch, 1794) & MZUEL 10437 & Nest & $\mathrm{X}$ & \\
\hline Hypostomus commersoni Valenciennes, 1836 & MZUEL 10240 & Nest & $\mathrm{X}$ & \\
\hline Iheringichthys labrosus (Lütken, 1874) & MZUEL 9586 & Semi-dense eggs & $\mathrm{X}$ & \\
\hline Oligosarcus jenynsii (Gunther, 1864) & MZUEL 10547 & Demersal eggs & & $\mathrm{X}$ \\
\hline Parapimelodus valenciennis (Lütken, 1874) & MZUEL 9585 & Semi-dense eggs & $\mathrm{X}$ & \\
\hline Piabarchus stramineus (Eigenmann, 1908) & MZUEL 10553/10555 & Semi-dense eggs & $\mathrm{X}$ & $\mathrm{X}$ \\
\hline Pimelodus maculatus LaCépède, 1803 & MZUEL 9599/9597 & Semi-dense eggs & $\mathrm{X}$ & $\mathrm{X}$ \\
\hline Prochilodus lineatus (Valenciennes, 1837) & MZUEL 11729 & Semi-dense eggs & $\mathrm{X}$ & \\
\hline Rhamdia quelen (Quoy \& Gaimard, 1824) & MZUEL 10549 & Semi-dense eggs & $\mathrm{X}$ & $\mathrm{X}$ \\
\hline Schizodon nasutus Kner, 1858 & MZUEL 10548 & Demersal eggs & $\mathrm{X}$ & \\
\hline Serrasalmus maculatus Kner, 1858 & MZUEL 9416 & Nest & $\mathrm{X}$ & \\
\hline Steindachnerina brevipinna (Eigenmann \& Eigenmann, 1889) & MZUEL 9491/10558 & Semi-dense eggs & $\mathrm{X}$ & $\mathrm{X}$ \\
\hline
\end{tabular}

Tab. 4. Total number of juveniles collected by species during the sampling period (2002-2012) in the Machadinho reservoir and (2001-2012) in the Itá reservoir.

\begin{tabular}{lcc}
\hline \multirow{2}{*}{ Species } & Machadinho & Itá \\
\cline { 2 - 3 } & Number of juveniles & Number of juveniles \\
\hline Acestrorhynchus pantaneiro & 41 & 48 \\
Apareiodon affinis & 55 & 1693 \\
Astyanax aff. fasciatus & 100 & 525 \\
Astyanax aff. scabripinnis & 0 & 44 \\
Astyanax jacuhiensis & 200 & 67 \\
Cyprinus carpio & 100 & 0 \\
Eigenmannia virescens & 24 & 0 \\
Geophagus brasiliensis & 281 & 245 \\
Hoplias lacerdae & 0 & 81 \\
Hoplias malabaricus & 0 & 83 \\
Hypostomus commersoni & 0 & 75 \\
Iheringichthys labrosus & 0 & 520 \\
Oligosarcus jenynsii & 187 & 0 \\
Parapimelodus valenciennis & 0 & 10 \\
Piabarchus stramineus & 215 & 656 \\
Pimelodus maculatus & 12 & 28 \\
Prochilodus lineatus & 0 & 17 \\
Rhamdia quelen & 22 & 62 \\
Schizodon nasutus & 0 & 111 \\
Serrasalmus maculatus & 0 & 125 \\
Steindachnerina brevipinna & 23 & 252 \\
\hline Total & 1,260 & 4,642 \\
\hline & & \\
\hline & 0 & 0 \\
\hline
\end{tabular}

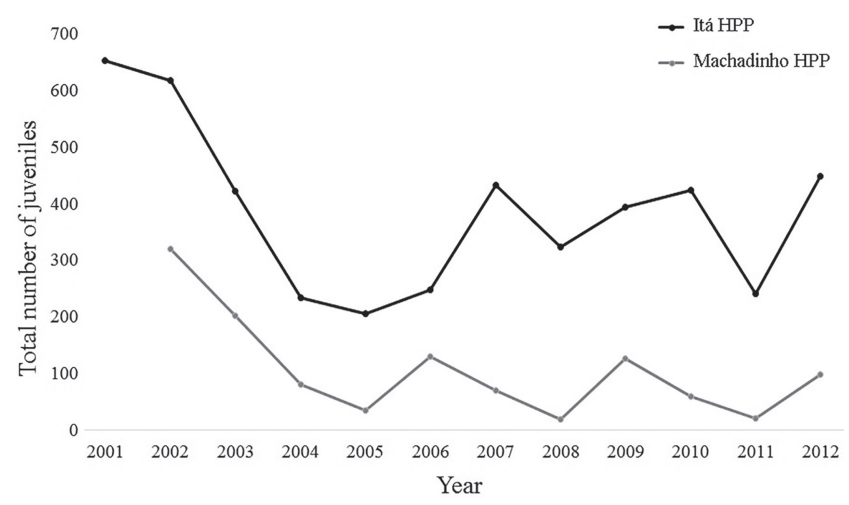

Fig. 2. Total number of juveniles annually collected during the sampling period in the Machadinho and Itá reservoirs.

The DCA 2 represented $16.8 \%$ of the data variation and showed the separation of the years in two different groups. The first was composed of the years 2005, 2006, 2009 and 2010, which were characterized by the presence of Serrasalmus maculatus $(\mathrm{r}=0.72 ; \mathrm{p}<0.05)$, Hoplias lacerdae $(\mathrm{r}=0.50 ; \mathrm{p}<0.05)$, Schizodon nasutus $(\mathrm{r}=0.42 ; \mathrm{p}$ $<0.05)$, I. labrosus $(\mathrm{r}=0.49 ; \mathrm{P}<0.05)$ and Parapimelodus valenciennis $(0.42 ; \mathrm{p}<0.05)$, while the second group, formed by the years 2004, 2007, 2008 and 2011, was more related to the larger presence of Prochilodus lineatus $(\mathrm{r}=$ $-0,61 ; \mathrm{P}<0.05)$, Steindachnerina brevipinna $(\mathrm{r}=-0.40 ; \mathrm{P}<$ $0.05)$ and Rhamdia quelen $(\mathrm{r}=-0.70 ; \mathrm{P}<0.05)$. 

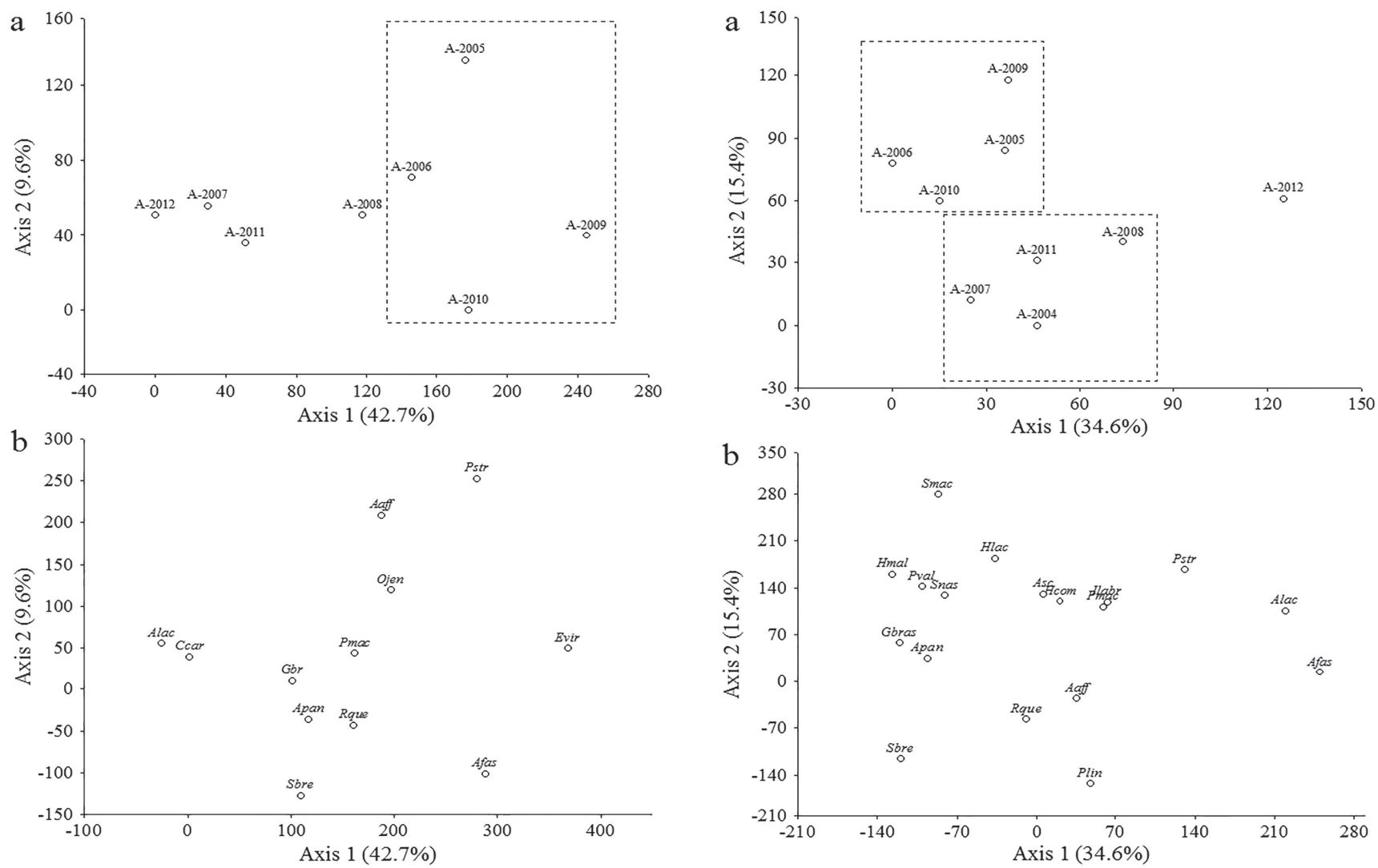

Fig. 3. Detrended Correspondence Analysis (DCA) for the Machadinho reservoir fish juveniles abundance data for the period between 2005 and 2012; a. spatial distribution of the years and b. temporal distribution of the species. Aaff: Apareiodon affinis; Afas: Astyanax aff. fasciatus; Alac: Astyanax lacustris; Apan: Acestrorhynchus pantaneiro; Ccar: Cyprinus carpio; Evir: Eigenmannia virescens; Gbra: Geophagus brasiliensis; Ojen: Oligosarcus jenynsii; Pmac: Pimelodus maculatus; Pstr: Piabarchus stramineus; Rque: Rhamdia quelen; Sbre: Steindachnerina brevipinna.

Correlation between hydrological parameters and the abundance of juveniles. The number of juveniles fish caught presented a similar pattern of correlation when related to the average level of water and the average storage volume of the Machadinho reservoir. When species were grouped according to reproductive strategy, both species that perform spawning in nests and those that release semi-dense eggs were generally negatively correlated with WL variations in the reservoir. Meanwhile, the species that spawn in macrophytes and the ones that release demersal eggs showed no significant correlation with any of the hydrological parameters analyzed. The total number of juveniles captured was negatively correlated with WL variations.

Of the 12 species caught during the study period in the Machadinho reservoir, seven had correlations above 0.40 (considering analyses from the PR5 reproductive period). The highest correlations were obtained with $R$. quelen $(0.89$ with AVRWL and AVSV) and S. brevipinna (0.70 with AVRWL and AVSV) (Tab. 5).

Fig. 4. Detrended Correspondence Analysis (DCA) for the Itá reservoir fish juveniles abundance data for the period between 2004 and 2012; a. spatial distribution of the years and b. temporal distribution of the species. Aaff: Apareiodon affinis; Afas: Astyanax aff. fasciatus; Alac: Astyanax lacustris; Apan: Acestrorhynchus pantaneiro; Ccar: Cyprinus carpio; Evir: Eigenmannia virescens; Gbra: Geophagus brasiliensis; Ojen: Oligosarcus jenynsii; Pmac: Pimelodus maculatus, Pstr: Piabarchus stramineus; Rque: Rhamdia quelen; Sbre: Steindachnerina brevipinna.

The correlations between the abundance of juveniles and the water parameters variation in the Itá reservoir showed a pattern similar to the correlations with storage volume. When the species were grouped by reproductive strategy, those species that spawn in nests mostly showed negative correlations with the variation in the reservoir WL. The species that use other reproductive strategies showed no significant correlation with any of the hydrological parameters assessed. In spite of that, the total number of juveniles captured was negatively correlated with changes in the WL in the Itá reservoir, although this correlation was stronger only after the fourth year after the reservoir formation.

The 18 species caught in the Itá reservoir throughout the whole study period, 10 showed correlations above 0.40 (considering the analysis from the PR4 reproductive period). The strongest correlations were obtained with the species Hoplias malabaricus (0.81 with AVSV) and G. brasiliensis (-0.72 with VRWL and VSV) (Tab. 6). 
A divergence among the two reservoirs was observed between the species that release semi-dense eggs; a positive correlation with a more stable WL was only observed in the
Machadinho reservoir. This result can be driven by a wider range of WL variation in Machadinho reservoir (typically twice) as compared to the Itá reservoir.

Tab. 5. Correlations between the hydrological parameters and the abundance of juveniles in the Machadinho reservoir, considering the entire sampling period (RP2 to RP12) and the period that excludes the first years after the formation of the reservoir (RP5 to RP12). ${ }^{1} \mathrm{VWL}=$ Variation (standard deviation) of the reservoir water level during the reproductive period. ${ }^{2} \mathrm{AWL}=$ Average value of the reservoir water level during the reproductive period. ${ }^{3} \mathrm{VSV}=$ Variation (standard deviation) of the reservoir storage volume during the reproductive period. ${ }^{4} \mathrm{ASV}=$ Average value of the reservoir storage volume during the reproductive period.

\begin{tabular}{|c|c|c|c|c|c|c|c|c|}
\hline & \multicolumn{2}{|c|}{ RP2-RP12 } & \multicolumn{2}{|c|}{ RP5-RP12 } & \multicolumn{2}{|c|}{ RP2-RP12 } & \multicolumn{2}{|c|}{ RP5-RP12 } \\
\hline & $\mathrm{VWL}^{1}$ & $\mathrm{AWL}^{2}$ & VWL & AWL & $\mathrm{VSV}^{3}$ & $\mathrm{ASV}^{4}$ & VSV & ASV \\
\hline Nest & -0.46 & 0.38 & -0.49 & 0.53 & -0.44 & 0.37 & -0.47 & 0.52 \\
\hline Spawning in macrophytes & -0.15 & -0.04 & -0.18 & 0.01 & -0.14 & -0.05 & -0.17 & 0.00 \\
\hline Semi-dense eggs & -0.09 & 0.36 & -0.52 & 0.82 & -0.08 & 0.36 & -0.50 & 0.82 \\
\hline Demersal eggs & -0.36 & 0.17 & -0.21 & -0.16 & -0.35 & 0.16 & -0.21 & -0.16 \\
\hline Cyprinus carpio & -0.26 & -0.02 & -0.30 & 0.03 & -0.26 & -0.03 & -0.29 & 0.02 \\
\hline Eigenmannia virescens & 0.30 & -0.06 & 0.32 & -0.05 & 0.31 & -0.05 & 0.34 & -0.05 \\
\hline Geophagus brasiliensis & -0.46 & 0.38 & -0.49 & 0.53 & -0.44 & 0.37 & -0.47 & 0.52 \\
\hline Acestrorhynchus pantaneiro & -0.48 & 0.25 & -0.66 & 0.40 & -0.47 & 0.24 & -0.65 & 0.39 \\
\hline Apareiodon affinis & -0.15 & 0.18 & -0.28 & 0.34 & -0.16 & 0.19 & -0.28 & 0.34 \\
\hline Astyanax aff. fasciatus & -0.30 & 0.57 & -0.34 & 0.53 & -0.28 & 0.58 & -0.33 & 0.54 \\
\hline Astyanax lacustris & -0.10 & -0.36 & -0.14 & -0.37 & -0.12 & -0.37 & -0.16 & -0.38 \\
\hline Piabarchus stramineus & 0.08 & 0.23 & 0.55 & 0.03 & 0.09 & 0.23 & 0.58 & 0.03 \\
\hline Oligosarcus jenynsii & -0.20 & 0.39 & 0.22 & 0.03 & -0.17 & 0.39 & 0.24 & 0.02 \\
\hline Pimelodus maculatus & -0.52 & -0.32 & 0.56 & -0.24 & 0.60 & -0.31 & 0.57 & -0.23 \\
\hline Rhamdia quelen & -0.52 & 0.79 & -0.68 & 0.89 & -0.49 & 0.79 & -0.66 & 0.89 \\
\hline Steindachnerina brevipinna & -0.55 & 0.43 & -0.65 & 0.70 & -0.54 & 0.42 & -0.63 & $\mathbf{0 . 7 0}$ \\
\hline Total of juveniles & -0.55 & 0.43 & -0.36 & 0.21 & -0.42 & 0.40 & -0.37 & 0.16 \\
\hline
\end{tabular}

Tab. 6. Correlations between the hydrological parameters and the abundance of juveniles in the Itá reservoir, considering the entire sampling period (RP1 to RP12) and the period that excludes the first years after the formation of the reservoir (RP4 to RP12). ${ }^{1} \mathrm{VWL}=$ Variation (standard deviation) of the reservoir water level during the reproductive period. ${ }^{2} \mathrm{AWL}=$ Average value of the reservoir water level during the reproductive period. ${ }^{3} \mathrm{VSV}=$ Variation (standard deviation) of the reservoir storage volume during the reproductive period. ${ }^{4} \mathrm{ASV}=$ Average value of the reservoir storage volume during the reproductive period.

\begin{tabular}{|c|c|c|c|c|c|c|c|c|}
\hline & \multicolumn{2}{|c|}{ RP1-RP12 } & \multicolumn{2}{|c|}{ RP4-RP12 } & \multicolumn{2}{|c|}{ RP1-RP12 } & \multicolumn{2}{|c|}{ RP4-RP12 } \\
\hline & $\mathrm{VWL}^{1}$ & $\mathrm{AWL}^{2}$ & VWL & AWL & $\mathrm{VSV}^{3}$ & $\mathrm{ASV}^{4}$ & VSV & ASV \\
\hline Nest & -0.27 & 0.03 & -0.66 & 0.48 & -0.27 & 0.21 & -0.66 & 0.63 \\
\hline Semi-dense eggs & -0.06 & 0.04 & -0.15 & -0.22 & -0.06 & 0.07 & -0.16 & -0.28 \\
\hline Demersal eggs & 0.13 & -0.22 & -0.07 & -0.02 & 0.13 & -0.21 & -0.07 & -0.10 \\
\hline Geophagus brasiliensis & -0.38 & 0.03 & -0.72 & 0.52 & -0.39 & 0.16 & -0.72 & 0.62 \\
\hline Hoplias lacerdae & 0.01 & 0.28 & 0.29 & -0.03 & 0.03 & 0.37 & 0.31 & 0.15 \\
\hline Hoplias malabaricus & -0.42 & 0.45 & -0.64 & 0.70 & -0.42 & 0.57 & -0.64 & 0.81 \\
\hline Hypostomus commersoni & 0.24 & 0.06 & 0.66 & -0.25 & 0.26 & 0.10 & 0.65 & -0.28 \\
\hline Serrasalmus maculatus & 0.18 & -0.45 & -0.13 & -0.07 & 0.17 & -0.31 & -0.14 & 0.08 \\
\hline Acestrorhynchus pantaneiro & -0.39 & 0.24 & -0.56 & 0.61 & -0.41 & 0.19 & -0.57 & 0.47 \\
\hline Apareiodon affinis & -0.04 & -0.10 & -0.07 & -0.22 & -0.05 & -0.14 & -0.03 & -0.25 \\
\hline Astyanax aff. fasciatus & 0.07 & -0.23 & -0.10 & -0.04 & 0.07 & -0.23 & -0.10 & -0.11 \\
\hline Astyanax aff. scabripinnis & 0.61 & -0.64 & 0.50 & -0.45 & 0.62 & -0.54 & 0.51 & -0.34 \\
\hline Astyanax lacustris & 0.14 & -0.32 & 0.69 & -0.15 & 0.14 & -0.39 & 0.04 & -0.25 \\
\hline Piabarchus stramineus & 0.01 & -0.12 & -0.22 & -0.05 & 0.01 & -0.04 & -0.23 & -0.05 \\
\hline Iheringichthys labrosus & -0.18 & 0.23 & -0.18 & 0.23 & -0.17 & 0.19 & -0.17 & 0.15 \\
\hline Parapimelodus valenciennis & -0.13 & 0.47 & -0.01 & 0.41 & -0.10 & 0.48 & 0.01 & 0.40 \\
\hline Pimelodus maculatus & 0.38 & -0.26 & 0.44 & 0.11 & 0.39 & -0.18 & 0.44 & -0.03 \\
\hline Prochilodus lineatus & 0.15 & -0.15 & 0.15 & -0.09 & 0.15 & -0.13 & 0.16 & -0.03 \\
\hline Rhamdia quelen & 0.08 & 0.15 & 0.19 & -0.12 & 0.10 & 0.22 & 0.19 & -0.07 \\
\hline Schizodon nasutus & 0.10 & 0.05 & -0.16 & 0.47 & 0.12 & 0.17 & -0.15 & 0.50 \\
\hline Steindachnerina brevipinna & -0.06 & 0.24 & -0.06 & -0.30 & -0.04 & 0.28 & -0.08 & -0.34 \\
\hline Total of juveniles & -0.04 & -0.04 & -0.40 & -0.01 & -0.07 & 0.04 & -0.41 & -0.04 \\
\hline
\end{tabular}




\section{Discussion}

Several studies have been conducted to assess the impact of dams on fish populations in the major river basins of Brazil (Agostinho et al., 2004b; Fernandes et al., 2009; HermesSilva et al., 2009; Gubiani et al., 2010; Reynalte-Tataje et al., 2012a), although they did not address the influence of these dams on fish recruitment.

According to these studies, the main impacts associated with the construction of hydroelectric power plants are those related to changes in the hydrological regime of the dammed rivers. This is because the attribute of WL variations is closely related to essential events in the life cycles and maintenance of fish stocks, such as migration, reproduction and recruitment of juveniles (Suzuki et al., 2009).

Meurer (2010) assessed the influence of the Itá dam on the composition of fish populations and the richness of fish species in the upper Uruguay River, noting that there were changes in fish community assembly and an increase in species richness after the impoundment, with an increase in opportunistic species.

In the present study, we observed there was a sharp decline in the total number of juveniles collected in the first four years following the formation of both Machadinho and Itá reservoirs, demonstrating that the construction of the dams has a significant influence on the ichthyofauna of the region. This result may be related to the fact that the first years after the impoundment of a reservoir are the most critical ones (Nogueira et al., 2006; Zaniboni-Filho et al., 2008). During this period, a lot of changes in many biotic and abiotic factors (e.g., the decomposition of flooded flora, water quality and water flow changes, etc.) make the environment unstable, and thus inappropriate or inaccessible to species that are more sensitive to such variations (Novakowski et al., 2007).

This period of instability in fish communities, observed in both reservoirs, minimized the effects of the variations of water levels on the abundance of juvenile fish. This condition is demonstrated by the low significance of the correlations between the number of juvenile fish of different species and the hydrological factors assessed during the first years after reservoirs formation. Such correlations became much more significant when these first years were discarded from the analysis.

Comparatively, the Itá reservoir showed a greater number of fish species and a greater abundance of juveniles. The proportion of individuals caught in Itá reservoir was higher than expected, and the average number of individuals was more than two times higher in Itá than in Machadinho reservoir, even standardizing fishing effort. Ichthyoplankton studies conducted in the upper Uruguay River region (Hermes-Silva et al., 2009; Reynalte-Tataje et al., 2012c) have shown that the reproductive activity of fish is much more intense in the area of Itá reservoir than of Machadinho. The scarcity of lotic environments located upstream Machadinho Dam has been credited as one of the factors that reduces reproductive activity (Hermes-Silva et al., 2009) and, consequently, interferes in the abundance of adult fish in this environment when compared with the Itá environment (Reynalte-Tataje et al., 2012c).

The correlations obtained in this study indicate the existence of a relationship between the recruitment of fish species and the hydrological parameters of the two reservoirs assessed. Most fish species are favored by the stability in the reservoirs' water levels. However, it was found that the responses of different fish species to the variables studied are related to reproductive guild, indicating that a given hydrological condition benefits the recruitment of some groups of fish species and hinders the recruitment of others.

The species spawning in nests, such as the pearl cichlid $G$. brasiliensis and the traíra (wolf fish, tiger fish) $H$. malabaricus (Santos, Fontoura, 2000, Chaves et al., 2009), have their recruitment impaired due to increased variations in the water levels of the reservoir. Agostinho et al. (2007) argue that fluctuations in water levels in the reservoir, as a result of the dam operations, can be disastrous for species that have eggs adhered to shoreline substrates, or that lay their eggs in nests built on the reservoir shoreline. This is because fluctuations in water levels can make these nests be exposed to the air and cause the mortality of the eggs, thus impairing the reproductive success of these species.

Similarly, the species that liberate semi-dense eggs, typical of populations that perform some type of reproductive migration, such as $R$. quelen and $S$. brevipinna, has higher reproductive success when the reservoir is full and has little variation in its WL, a condition characteristic of periods with high rainfall and high volume of water in the rivers.

Other groups of fish also had increased recruitment when the volume of water in the reservoirs were full, among them the zooplanktophagus species $P$. valenciennis and A. fasciatus (Nunes, 2009; Barbosa, Matsumura-Tundisi, 1984), or during flood period in rivers for the herbivorous S. nasutus, as presented by Villares-Junior et al. (2011). According to Yamamoto et al. (2004), the zooplankton community increases its abundance and richness during floods and decreases its abundance and richness during the dry season. Similarly, according to Veríssimo (1999), herbivorous species are benefited by flood seasons, due to the large supply of food in those periods, when a large part of the vegetation remains flooded for a longer period of time. Thus, the availability of food resources for herbivorous species shows remarkable fluctuations with the oscillation of water levels (Agostinho et al., 2007).

The increase in the population of Acestrorhynchus pantaneiro, a piscivorous species that became the most abundant in the upper Uruguay River region after the impoundment of the reservoirs (Meurer, 2010), may be related to the increase in the populations of forage species, such as A. fasciatus and S. brevipinna. Meurer, ZaniboniFilho (2012) and Cantanhêde et al. (2008) observed that $A$. pantaneiro shows opportunistic behavior, feeding on the most abundant species in the environment. In the upper Uruguay River, the species $A$. fasciatus and S. brevipinna are extremely abundant in the Itá and Machadinho reservoirs, 
and in this study they showed an increase in the abundance of juveniles during fuller reservoir conditions. These species are an important component of the diet of $A$. pantaneiro (Meurer, Zaniboni-Filho, 2012).

A different pattern was observed for species that shows an opportunistic behavior (Polis, Strong, 1996), such as P. stramineus, A. lacustris, Astyanax aff. scabripinnis and Pimelodus maculatus, which are benefited with the increase in the variations of the reservoir water levels. These species are characterized as generalists and omnivores, able to explore almost all trophic levels in aquatic systems.

Agostinho et al. (2007) already emphasized that broader and random fluctuations in water levels can lead to fluctuations in the populations of equilibrium species (k-strategists) and specialized trophic guilds. It can be inferred that the population depletion of the more specialized species in years with greater variations in water levels of the reservoirs would allow an increase of this group of more generalist fish, which would take advantage of habitat and resources that have become available in the reservoir.

In the aquatic environment, the network of interactions is extremely complex and dynamic; therefore, no population dynamics can be analyzed individually only because of their biology (e.g., morphology, feeding habits, breeding habits, etc.). It is also necessary to consider their interactions with the environment and with other species, which compete for habitat and food resources for their survival. Moreover, the species maintain an extremely direct and dependent relationship on the environment in which they live, and therefore any change in that environment can restructure populations and the relationships among them, changing the trophic chain and the dynamics of interactions.

These results showed the importance of studies that assess the impact of dams on fish recruitment, specially the direct and indirect effect of WL variation from reservoirs on the recruitment of the different reproductive guilds in several consecutive years. The variations in the WL of the Itá and Machadinho reservoirs have influence on the recruitment of juveniles in the upper Uruguay River region, but only species that spawn in nests are strongly negatively affected by the WL variation and species that release semi-dense eggs are apparently affected negatively when the variation in the WL is high. This information can be used in WL management to manipulate annual recruitment of some fish species.

\section{Acknowledgments}

The authors thank the Conselho Nacional de Desenvolvimento Científico e Tecnológico $(\mathrm{CNPq})$ for the Master scholarship for the first author and the productivity grant for the last author. We thank $\mathrm{CNPq}$, Fundação de Amparo à Pesquisa e Inovação do Estado de Santa Catarina (FAPESC) and Tractebel Energy for funding the fieldwork. We also thank Dra. Josiane Ribolli for the preparation of figure 1 and Dra. Samara Hermes-Silva for the final revision on the manuscript.

\section{References}

Agostinho AA, Hahn NS. Ciclo reprodutivo e primeira maturação de fêmeas de Hypostomus commersonii (Valenciennes, 1840) (Siluriformes, Loricariidae) no reservatório CapivariCachoeira, PR. Rev Bras Biol. 1991; 51(1):31-37.

Agostinho AA, Gomes LC, Veríssimo S, Okada EK. Flood regime, dam regulation and fish in the Upper Paraná river: effects on assemblage attributes, reproduction and recruitment. Rev Fish Biol Fish. 2004a; 14(1):11-19.

Agostinho AA, Thomaz SM, Gomes LC. Threats for biodiversity in the floodplain of the Upper Paraná river: effects of hydrological regulation by dams. Ecohydrol Hydrobiol. 2004b; 4(3):255-68.

Agostinho AA, Gomes LC, Pelicice FM. Ecologia e manejo de recursos pesqueiros em reservatórios do Brasil. Maringá: Eduem; 2007.

Alves MF. Biologia reprodutiva e alimentar da pequira Bryconamericus stramineus (Eigenmann, 1908) no elevador da represa do Funil - MG. [MSc Dissertation] Lavras: Universidade Federal de Lavras; 2009.

Barbosa PMM, Matsumura-Tundisi T. Consumption of zooplanktonic organisms by Astyanax aff. fasciatus Cuvier, 1819 (Osteichthyes, Characidae) in Lobo (Broa) Reservoir, São Carlos, SP, Brazil. Netherlands: Springer; 1984. (Tropical Zooplankton, Developments in Hydrobiology, vol 23).

Baumgärtner D, Mörtl M, Rothhaupt KO. Effects of waterdepth and water-level fluctuations on the macroinvertebrate community structure in the littoral zone of Lake Constance. Hydrobiologia. 2008; 613(1):97-107.

Cantanhêde G, Hahn NS, Fugi R, Gubiani EA. Alterations on piscivorous diet following change in abundance of prey after impoundment in a Neotropical river. Neotrop Ichthyol. 2008; 6(4):631-36.

Chaves MF, Torelli J, Targino CH, Crispim MC. Dinâmica reprodutiva e estrutura populacional de Hoplias aff. malabaricus (Bloch, 1794) (Characiformes, Erythrinidae), em açude da Bacia do Rio Taperoá, Paraíba. Biotemas. 2009; 22(2):85-89.

Consórcio Machadinho. Usina Hidrelétrica de Machadinho [Internet]. 2013 [cited 2013 Mar 22]. Available from: http:// www.machadinho.com.br/

Corrêa RN, Hermes-Silva S, Reynalte-Tataje DA, Zaniboni-Filho E. Distribution and abundance of fish eggs and larvae in three tributaries of the Upper Uruguay river (Brazil). Environ Biol Fishes. 2011; 91(1):51-61.

Dutterer AC, Mesing C, Cailteux R, Allen MS, Pine WE, Strickland PA. Fish recruitment is influenced by river flows and floodplain Inundation at Apalachicola river, Florida. River Res Appl. 2013; 29(9):1110-18.

Fernandes R, Agostinho AA, Ferreira EA, Pavanelli CS, Suzuki HI, Lima DP, Gomes LC. Effects of the hydrological regime on the ichthyofauna of riverine environments of the Upper Paraná river floodplain. Braz J Biol. 2009; 69(2):669-80.

Froese R, Pauly D, editors. FishBase. Serrasalmus maculatus [Internet]. 2017 [updated 2017 Jun]; Available from: http:// www.fishbase.org/summary/Serrasalmus-maculatus.html

Gubiani EA, Gomes LC, Agostinho AA, Baumgartner G. Variations in fish assemblages in a tributary of the upper Parana river, Brazil: a comparison between pre and post closure phases of dams. River Res Appl. 2010; 26(7):848-65.

Hermes-Silva S, Reynalte-Tataje DA, Zaniboni-Filho E. Spacial and temporal distribution of ichthyoplankton in the Upper Uruguay river, Brazil. Braz Arch Biol Technol. 2009; 52(4):933-44. 
Meurer S. Implantação de barragens no Alto Rio Uruguai (Brasil): influência sobre a assembleia e biologia das principais espécies de peixes. [PhD Thesis on the internet]. Florianópolis, SC: UFSC; 2010. Available from: Biblioteca digital Universidade Federal de Santa Catarina. http://www.tede.ufsc.br/teses/PAQI0259-T.pdf

Meurer S, Zaniboni-Filho E. Reproductive and feeding biology of Acestrorhynchus pantaneiro Menezes, 1992 (Osteichthyes: Acestrorhynchidae) in areas under the influence of dams in the upper Uruguay River, Brazil. Neotrop Ichthyol. 2012; 10(1):159-66.

Miranda LE. A review of guidance and criteria for managing reservoirs and associated riverine environments to benefit fish and fisheries. In: Marmulla G, editor. Dams, fish and fisheries Opportunities, challenges and conflict resolution. Rome: FAO; 2001. p.91-138.

Nakatani K, Agostinho AA, Baumgartner G, Bialetzki A, Sanches PV, Makrakis MC, Pavanelli CS. Ovos e larvas de peixes de água doce: desenvolvimento e manual de identificação. Maringá: Eduem; 2001.

Nogueira MG, Jorcin A, Viana NC, Britto YCT. Reservatórios em cascata e os efeitos na limnologia e organização das comunidades bióticas (fitoplâncton, zooplâncton e zoobentos): um estudo de caso no rio Paranapanema (SP/PR). In: Nogueira MG, Henry R, Jorcin A, editors. Ecologia de reservatórios: impactos potenciais, ações de manejo e sistemas em cascata. 2nd ed. São Carlos: RIMA; 2006. p.83-126.

Novakowski GC, Hahn NS, Fugi R. Feeding of piscivorous fish before and after the filling of the Salto Caxias Reservoir, Paraná State, Brazil. Biota Neotrop. 2007; 7(2):149-54.

Nunes MC. Ictiofauna associada ao cultivo de peixes em tanques-rede no reservatório da Usina Hidrelétrica de Itá, Alto rio Uruguai, Brasil. [MSc Dissertation on the internet]. Florianópolis, SC: UFSC; 2009. Available from: Biblioteca digital Universidade Federal de Santa Catarina. http://www. tede.ufsc.br/teses/PAQI0228-D.pdf

Paulovits G, Borbély G, Tóth LG, Kováts N. Effects of water level fluctuation on reproduction and spawning habitats of fish species in Lake Balaton. Environ Eng Manag J. 2007; 6(5):467-71.

Petry AC, Abujanra F, Gomes LC, Julio Jr. HF, Agostinho AA. Effects of the interannual variations in the flood pulse mediated by hypoxia tolerance: the case of the fish assemblages in the upper Paraná river floodplain. Neotrop Ichthyol. 2013; 11(2):413-24.

Polis GA, Strong DR. Food web complexity and community dynamics. Am Nat. 1996; 147(5):813-46.

Pompeu PS, Godinho HP. Effects of extended absence of flooding on the fish assemblages of three floodplain lagoons in the middle São Francisco River, Brazil. Neotrop Ichthyol. 2006; 4(4):427-33.

Reynalte-Tataje DA, Zaniboni-Filho E. Biologia e identificação de ovos e larvas de peixes do alto rio Uruguai. In: ZaniboniFilho E, Nuñer APO. Reservatório de Itá. Estudos ambientais, desenvolvimento de tecnologia e conservação da ictiofauna. Florianópolis: Editora da UFSC; 2008. p.229-256.

Reynalte-Tataje DA, Nuñer APO, Nunes MC, Garcia V, Lopes CA, Zaniboni-Filho E. Spawning of migratory fish species between two reservoirs of the upper Uruguay river, Brazil. Neotrop Ichthyol. 2012a; 10(4):829-35.

Reynalte-Tataje DA, Zaniboni-Filho E, Bialetzki A, Agostinho AA. Temporal variability of fish larvae assemblages: influence of natural and anthropogenic disturbances. Neotrop Ichthyol. 2012b; 10(4):837-46.
Reynalte-Tataje DA, Agostinho AA, Bialetzki A, Hermes-Silva S, Fernandes R, Zaniboni-Filho E. Spatial and temporal variation of the ichthyoplankton in a subtropical river in Brazil. Environ Biol Fishes. 2012c; 94(2):403-19.

Reynalte-Tataje DA, Zaniboni-Filho E, Hermes-Silva S, Machado C, Guereschi R, Nuñer APO. Assembleia de peixes. In: Nuñer APO, Zaniboni-Filho E, organizers. Reservatório de Machadinho: peixes, pesca e tecnologias de criação. Florianópolis: Editora da UFSC; 2012d. p.11-44.

Santos GO, Fontoura NF. Dinâmica reprodutiva de Geophagus brasiliensis (Quoy \& Gaimard, 1824), no açude Águas Belas, Viamão, Rio Grande do Sul, (Teleostei - Cichlidae). Pesquisa Agropecuária Gaúcha. 2000; 6(1):131-44.

Suzuki HI, Agostinho AA, Bailly D, Gimenes MF, Júlio-Junior HF, Gomes LC. Inter-annual variations in the abundance of youngof-the-year of migratory fishes in the Upper Paraná River floodplain: relations with hydrographic attributes. Braz J Biol. 2009; 69(2):649-60.

Tractebel Energia. UHE Itá [Internet]. 2013. [cited 2013 Mar 22]. Available from: http://www.tractebelenergia.com.br/ wps/portal/internet/corporativo/parque-gerador/usinashidreletricas/uhe-ita/

Vazzoler AEAM. Biologia da reprodução de peixes teleósteos: teoria e prática. Maringá: Eduem; 1996.

Veregue AML, Orsi ML. Biologia reprodutiva de Astyanax scabripinnis paranae (Eigenmann) (Osteichthyes, Characidae), do ribeirão das Marrecas, bacia do rio Tibagi, Paraná. Rev Bras Zool. 2003; 20(1):97-105.

Veríssimo S. Influência do regime hidrológico sobre a ictiocenose de três lagoas da planície aluvial do Alto rio Paraná. [PhD Thesis]. São Carlos: Universidade Federal de São Carlos; 1999.

Villares-Junior GA, Gomiero LM, Goitein R. Biological aspects of Schizodon nasutus Kner, 1858 (Characiformes, Anostomidae) in the low Sorocaba river basin, São Paulo state, Brazil. Braz J Biol. 2011; 71(3):763-70.

Yamamoto KC, Soares MGM, Freitas CEC. Alimentação de Triportheus angulatus (Spix \& Agassiz, 1829) no lago Camaleão, Manaus, AM, Brasil. Acta Amaz. 2004; 34(4):653-59.

Zaniboni-Filho E, Schulz UH. Migratory fishes of the Uruguay river. In: Carolsfeld J, Harvey B, Ross C, Baer A, editors. Migratory fishes of the South America: biology, social importance and conservation status. Victoria: World Fisheries Trust; 2003. p.135-168.

Zaniboni-Filho E, Nuñer APO, Reynalte-Tataje DA, HermesSilva S, Meurer S. Alterações espaciais e temporais da estrutura da comunidade de peixes em decorrência da implantação do reservatório de Itá (alto rio Uruguai). In: Zaniboni-Filho E, Nuñer APO, editors. Reservatório de Itá: estudos ambientais, desenvolvimento de tecnologias de cultivo e conservação da ictiofauna. Florianópolis: Editora da UFSC; 2008. p.21-48.

Zohary T, Ostrovsky I. Ecological impacts of excessive water level fluctuations in stratified freshwater lakes. Inland Waters. 2011; 1(1):47-59. 